\title{
Review on Genetic Diversity of Coffee (Coffea Arabica.L) in Ethiopia
}

\author{
Desalegn Alemayehu \\ Post Graduate student, Jimma University College of Agriculture, Department of Horticulture and \\ Plant Sciences, Ethiopia.
}

\begin{abstract}
Ethiopia is the homeland and center of genetic diversity of Arabica coffee (Coffea arabica L., Rubiaceae). The entire genetic diversity of indigenous (wild) Arabica coffee is confined mainly in the afromontane rain forest located in the west and east of Great Rift Valley. Different research findings were reviewed and cited on the genetic diversity and its importance to the Ethiopian coffee breeding programs for high productivity and disease resistance. The objective of this paper is to review on the genetic diversity of coffee (coffea arabica.L) in Ethiopia based on different marker traits (morphological and molecular markers). The evidence which indicates the existence of arabica coffee genetic diversity in Ethiopia were reviewed and cited in the body of this paper. The indicators includes genotypic and phenotypic variability, Combining ability in Arabica coffee, Existence of heterosis in coffee Arabica and the achievements made were cited as the major evidences those indicates the presence of genetic diversity in Arabica coffee in Ethiopia.
\end{abstract}

Keywords: Arabica coffee; genetic diversity; marker traits; morphological markers; moleculer markers

\section{INTRODUCTION}

Coffee (Coffea arabica L.) belongs to the genus Coffea, in the family of Rubiaceae, and is mostly grown in the tropical and subtropical regions (Berthaud \& Charrier 1988). Arabica coffee is grown in about 80 countries spanning over 10.2 million hectares of land in the tropical and subtropical regions of the world, especially in Africa, Asia and Latin America. Coffee is known to be one of the most important beverages in the world. It has a current estimated value of US $\$ 10$ billion and is one of the most traded commodities second in value only to oil and a huge contributor of foreign exchange earnings for developing countries (Labouisse et al., 2008). More than 125 million people in the coffee growing areas worldwide derive their income directly or indirectly from its products in cultivation, processing, trading, transportation and marketing (Lashermes et al., 2011). Arabica coffee (Coffea arabica) is one of the world's most valuable agricultural commodities which accounts for two-thirds of the global coffee market (Labouisse et al., 2008) and it ranks second after oil in international trade (Geromel et al., 2006).

Ethiopia is producing an estimated 9.8 million bags that would rank the country as the third largest coffee producer in the world after Brazil and Vietnam, beating out Colombia (ICO, 2012) and the fifth major exporter of Arabica coffee globally next to Brazil, Vietnam, Colombia and Indonesia and the highest producer of coffee in all of African country (Davis et al., 2012). Currently it contributes about 30 present of the country's foreign currency earnings. More than 15 million people directly or indirectly depend on coffee value chain for their income and employment. About $35 \%$ of the total production is consumed within the producing areas (Chauhan et al., 2015) and in general, over 50\% of the coffee produced is consumed within Ethiopia (Bart et al., 2014).

The crop is mainly produced in the Southern, South Western and Eastern parts of the country. The total area coverage of coffee in Ethiopia is estimated to be around 800,000 ha, of which about $95 \%$ is produced by 4 million small scale farmers (Berhanu et al., 2015); whereas the estimated annual national production of coffee is about 419, 980.20 tons.

Ethiopia is the homeland and center of genetic diversity of Arabica coffee (Coffea arabica L., Rubiaceae) (Vavilov 1951).The entire genetic diversity of indigenous (wild) Arabica coffee is confined mainly in the afromontane rain forest located in the west and east of Great Rift Valley (Taye and Jurgen, 2008). Different research findings illustrate the importance of the Ethiopian coffee genetic materials in breeding programs for high productivity and disease resistance (Labouisse et al., 2008; Adugna, 2005). Ethiopian C. arabica accessions were used as parents and crossed with commercial varieties to obtain strong hybrid vigor, resulting in over $34 \%$ higher productivity of the F1 hybrids in full sun in Central America (Bertrand et al., 2011). 
In Eastern Africa, the outbreak of the coffee berry disease in the 1970s and 1980s larger damage were caused. In Ethiopia the disease does not affect coffee production significantly, chiefly due to the availability of high genetic diversity which enabled to develop cultivars resistant to the disease in a very short time using materials from the wild coffee gene pool (Mesfin and Bayetta 1984). Hence, there is no doubt that the existence of a gene pool with wide genetic variability can safeguard coffee production from dangers posed by possible disease outbreaks and environmental stresses.

\section{GeNETIC Diversity In COFFEe ARABICA}

Variability is the occurrence of differences among individuals due to differences in their genetic composition and/or the environment in which they are raised (Allard, 1960). Genetic variability, which is due to the genetic differences among individuals within a population, is the core of plant breeding because proper management of diversity can produce permanent gain in the performance of plant and can buffer against seasonal fluctuations (Sharma, 1998). These genetic variations can be enumerated at three levels: species, populations and individual levels. Since Ethiopia is the only centers of origin and diversifications of Coffea arabica, there is a high genetic diversity, which is mainly attributed to its diverse ecological features such as suitable altitude, ample rainfall, optimum temperature, fertile soils etc. and the presence of indigenous methods of coffee production system in the country (Yeshitila et al., 2004; Gole et al., 2001).

More genetically diverse strains of C. Arabica exist in Ethiopia than anywhere else in the world, which has lead botanists and scientists to consent that Ethiopia is the center for origin, diversification and dissemination of the coffee plant (Mekuria et al., 2004). Several phenotypic and molecular studies revealed that the populations of $C$. arabica from the southwestern part of Ethiopia have high genetic variability, and the forests there are thus suitable for in situ conservation of the species. For example, Sylvian (1958) and Meyer (1968) observed a high diversity of several phenotypic characters among the Ethiopian coffee populations. Montagnon and Bouharmont (1996) also found higher phenotypic diversity among the populations of $C$. arabica collected from Ethiopia as compared to cultivated populations of the species from around the world. According to the study of genetic variation among forty nine Coffea arabica accessions from Limu, Ethiopia confirmed the presence of trait diversity within coffee accessions (Olika et al., 2011). The study of genetic variation among 100 Coffea arabica accessions from Hararghe, Ethiopia were also confirmed the presence of trait diversity within 14 characters suggesting that the presence of high variability among the accessions Kebede \& Bellachew 2004; Kebede \& Bellachew 2008).

Higher level of genetic variability with molecular markers was observed among spontaneous and sub spontaneous accessions of this species collected from Ethiopia (Anthony et al., 2001). The existence of two subgroups of partial genetic differentiation within germplasm of C. arabica into accessions collected from east (Kaffa, Ilubabor, Welega) and west (Sidamo, Harrarge) of Great Rift Valley was established by an analysis with molecular markers (RAPD) (Lashermes et al., 1996) and also by a multivariate analysis of phenotypic characters (Montagnon \& Bouharmont, 1996) In this perspective it would appear that the coffee cultivated in Yemenfrom where almost all cultivated C. arabica derive, had its origin in Ethiopia east of the Rift Valley (Van der Vossen, 2001)

\section{MARKERS USED FOR DETECTING GENETIC DIVERSITY}

\section{Morphological Marker}

Morphological characteristics were among the earliest genetic markers used for assessment of variation and are still of great importance. Usually, these characters are inexpensive and simple to score. The sharing of physical features is also often accepted as an indication of relatedness. There are several sets of physical character assessment for different crops at different developmental stages such as seed, juvenile, adult vegetative, flower and fruit. However, these sets of characters lack adequate coverage of the genome, are strongly influenced by environmental factors, and are apparently controlled by several genes (Wang \& Tanksley, 1989). Besides, assessment of morphological characters in perennial plants such as coffee, often require a lengthy and expensive evaluation during the whole vegetative growth. Morphological markers are cheap and easy to apply; they are sensitive to environmental influences and developmental stage of the plant. Different scholars reported that although agro-morphological characters are often influenced by environmental conditions, the method is still useful and easy to apply for classification, estimating diversity and registration of cultivars.

Sylvain (1955) classified Ethiopian cultivated coffee into 13 main types namely, Agaro, Arbagugu, Cioiccie, Coulo, Dilla, Ennarea, Harar, Irgalem, Keffa, Tafari Kela, Wolkite, Wollamo and Zeghie 
using only bean and fruit morphology. Montagnon and Bouharmont (1996) classified wild and cultivated coffee genotypes from Ethiopia according to their geographic origin using 18 agromorphological traits. The FAO coffee collection team has observed phenotypic variation in branching habit, young leaf colour, fruit colour, persistence of sepals, leaf and fruit size. Ameha (1986) observed growth habit variation such as compact and spreading type genotypes from national coffee collections. Likewise, Selvakumar and Sreenivasan (1989) observed phenotypic variation among 54 coffee accessions collected from Keffa province of Ethiopia. In coffee, it is important to identify the most suitable age of a tree when characters can be measured easily and with utmost accuracy because coffee is a perennial crop. Walyaro (1983) reported that characters such as tree height, girth of the stem, internode length measured on the main stem and primaries and radius of canopy can be accurately determined using a single measurement even on young trees, 18 months after field planting.

Genetic studies in arabica coffee have shown that selection efficiency for higher bean yield can be increased by taking into account various growth parameters and yield components, such as stem girth, canopy radius, percentage of bearing primaries, percentage of bearing nodes and number of berries per node (Van der Vossen, 1985).

\section{Molecular Marker}

Molecular markers have been replacing or complementing traditional morphological and agronomic characterization, since they are virtually unlimited, cover the whole genome, are not influenced by the environment, and less time consuming. Each molecular marker has its advantages and drawbacks. Application of molecular marker techniques to diversity questions must take into account whether or not the data derived from a technique provide the right type of information for answering the question being addressed (Karp et al., 1997). The choice of appropriate molecular markers depends on the taxonomic levels of the material being studied (different species, subspecies, populations, cultivars and individuals). The closer the relationship of the materials to be studied, the more necessary it may be to consider highly discriminatory techniques. Besides, the choice of appropriate molecular markers also depends on the accessibility and cost effectiveness of the marker techniques.

Knowledge of genetic diversity within and among genotypes of any crop is fundamental for estimation of the potential genetic gain in a breeding program and effective conservation of available genetic resources. Currently, different molecular marker techniques are being developed for measuring genetic diversity. Comparison among molecular marker techniques is important for effective marker selection. However such types of efforts are rare for arabica coffee. Forest coffee populations in Ethiopia to determine the extent and distribution of its genetic diversity using PCR based DNA marker techniques such as random amplified polymorphic DNA (RAPD), inverse sequence-tagged repeat (ISTR), inter-simple sequence repeats (ISSR) and simple sequence repeat (SSR) or microsatellites (Powell et al., 1996). These molecular marker techniques are relatively simple and cost effective that can screen a larger portion of the genome, and are thus promising marker types for the identification of variation among the forest coffee samples collected from Ethiopia. In coffee, DNA-based molecular marker technology has already been implemented in germplasm characterization and management, detecting genetically divergent breeding subpopulations (for example to predict hybrid vigour), establishing gene introgression from related species and molecular marker-assisted selection (Lashermes et al., 1996). However, the molecular phylogeny of Coffea species has been established using DNA sequence data. The molecular markers have revealed an extremely reduced genetic diversity in Coffea arabica L. in comparison to C. canephora (Etienne et al., 2002).

\section{Random Amplified Polymorphic DNA (RAPD)}

RAPD (randomly amplified polymorphic DNA) markers generated by arbitary decamers have been successfully employed to detect genetic polymorphisms between coffee species and between Coffea arabica genotypes. The RAPD profiles were used to construct dendrograms and these were consistent with the known history and evolution of Coffea arabica. Material originating from Ethiopia and the arabica sub-groups C. arabica var. typica and C. arabica var. bourbon were clearly distinguished. RAPD analysis therefore reflects morphological differences between the sub-groups and the geographical origin of the coffee material. Orozco-Castillo et al. (1994) demonstrates the power of the polymerase chain reaction technology for the generation of genetic markers for long-lived perennial tree and bush crops. 


\section{Amplified Fragment Length Polymorphism (AFLP)}

Amplified fragment length polymorphisms are DNA fragments obtained from endonuclease restriction, followed by ligation of oligonucleotide adapters to the fragments and selective amplification by the polymerase chain reaction (PCR). Pearl et al. (2004) used AFLPs to construct a genetic linkage map on a pseudo-F2 population of arabica coffee (Coffea arabica L.) derived from a cross between the cultivars Mokka hybrid and Catimor. Sixty trees from this population were selected on the basis of plant height distribution to construct a linkage map. A total of 456 dominant markers and eight co-dominant markers were generated from 288 AFLP primer combinations. Of the total number of markers generated, $68 \%$ were from cv. Catimor, $30 \%$ from cv. Mokka hybrid, and 2\% were co-dominant. This distribution suggests that the heterozygosity within the cv. Catimor subgenomes was twice that within the cv. Mokka hybrid sub-genomes. Linkage groups were constructed using MAPMAKER version 3.0, resulting in 16 major linkage groups containing 4-21 markers, and 15 small linkage groups consisting of 2-3 linked markers each. The total length of the map was $1,802.8 \mathrm{cM}$, with an average distance of $10.2 \mathrm{cM}$ between adjacent markers. This genetic map will serve as the framework for mapping QTL controlling source-sink traits in the same population.

\section{Simple Sequence Repeat SSR and ISSR}

About 22 SSR fragments were amplified and compared with 712 amplified AFLP fragments. AFLP and SSR markers were positively and significantly correlated (0.217) in estimating genetic similarity among genotypes (Dessalegn et al., 2009). The average genetic similarity coefficient calculated using SSR markers was much lower (0.560 with a range of 0.286-1.000) compared to AFLP markers (0.915 with a range of 0.860-0.982) indicating the higher information content of SSR markers. AFLP markers distinguished all genotypes, while SSR markers distinguished $64.3 \%$ of the genotypes. Dessalegn et al. (2009) indicated that AFLP markers were more efficient compared to SSR markers for characterization of the evaluated coffee genotypes. Molecular markers provide the best estimate of genetic diversity since they are independent of the confounding effects of environmental factors (Powell et al., 1995). The use of molecular markers of the SSR and ISSR types in the study of diversity was efficient in carrying out the molecular characterization of coffee genotypes between and within C. arabica and C. canephora. Motta et al. (2014) reported that microsatellites markers were efficient in estimating the genetic similarity and could be used to increase the efficiency in classifying the materials and selecting the candidates for parental crosses.

\section{INDICATORS OF ARABICA COFFEE GENETIC DIVERSITY}

\section{Phenotypic and Genotypic Variation}

Naturally occurring genetic variability is useful in any plant breeding program. It is the amount of the total genotypic and phenotypic variability that exists in a crop germplasm dictates the initiation of crop improvement programs and develops better varieties. Of the total variability present in a population the genetic component is most important to the breeder as it could be transmitted to the progeny. In addition, proper management of this type of variability can produce permanent gain in the performance of the crop concerned (Mayo, 1980 and Welsh, 1990). In Ethiopia the geographic allocation of coffee within its homeland is good indication for the existence of genetic variation within a population. Variability in coffee Arabica has been reported to exist in different locality, where the crop is grown. Different cultivars have been distinguished on the basis of morphological (plant height, branching habit, leaf colour, leaf shape interenode length bean size, stem girh etc). Wide range of variability with respect to these characters has been observed for different accessions. Such traits of variability have been enabled Ethiopian coffee breeders in screening of selected coffee berry diseases resistant varieties and heterotic hybrid cultivars through crossing (Mesfin and Bayeta, 1987).

There are different Arabica coffee cultivars and landraces with desirable traits (yield, quality, disease resistance, drought stress tolerance, etc). The local coffee landraces are known by vernacular names and growth characteristics in the different localities. According to Yacob et al. (1996), they are broadly grouped into three canopy classes of open, intermediate and compact types. These arabica coffee species could be bourbon or typical cultivars as they are quite different in shoot and root growth systems as well as adaptation to specific site and respond to management inputs. They also vary in frequency of occurrence along rainfall gradients and soil profile depths (Taye et al., 2004), indicating the existing variability among the cultivated coffee landraces in their adaptation strategies under specific environments. Arabica coffee cultivars with open and compact crown habits were 
found to escape soil moisture stress through deeper and shallow root distribution as well as leaf shedding and rolling, respectively. Moreover, research findings (Kufa 2006; Beining 2008) also reveal the presence of significant diversity in drought adaptation and avoidance mechanisms among the wild coffee populations in Ethiopia.

The heritability of an agro-morphological character indicates the importance of a particular character for characterization of genotypes. Walyaro (1983) reported high narrow sense heritability for the following characters: girth $(0.50-0.61)$, tree height $(0.77-0.78)$, number of primaries $(0.58-0.62)$, angle of primary with the main stem $(0.56-0.62)$, canopy radius $(0.44-0.50)$, internode length on primaries (0.51-0.63) and bearing primaries (0.51-0.53). Several correlation studies indicated that the quantitative characters like number of stem nodes, primary branches, plant height, length of the longest primary branch and stem diameter etc. have positive and negative correlation with yield and such traits could be used as a selection criterion for improving the productivity of the crop since they represent the lion's share in the variability of the coffee population in the specified area (Gessese et al., 2015).

\section{Combining Ability in Arabica Coffee}

The GCA and SCA of five indigenous coffee (Coffea arabica L.) lines namely 75227, 744, 74148, F34 and 206/71 from south western coffee growing areas of the country is significant for yield, growth parameters, leaf, fruit and bean characters (Ayano et al., 2014). These indicate both additive and non-additive gene actions are involved in the inheritance of these traits. However, the relative contribution of SCA was $70 \%$ for yield indicating the predominance of non-additive gene action for inheritance of this important trait. For the fruit and bean traits the relative contribution of GCA suggested predominance of additive gene action. Parental line P4 showed good combining ability for three growth characters (stem girth, length of first primary branch and internode length) showing significant and positive GCA effects and this parent may contribute favorable alleles for the synthesis of vigorous hybrids. Cross combinations 75227xP5, 744x F34, 744x206/71 and 74148x206/71 showed positive and significant SCA effects for plant height. Cross combinations 74148x206/71, 75227x206/71, 744xP5, 744x F34 and 74148x F34 were good combinations for yield. On the other hand, only cross combinations $75227 \times 74148$ expressed negative SCA effects for yield which is undesirable as these cross showed a tendency to reduce yield performance (Ayano et al., 2014). For hundred bean weight, 75227x206/71, 74148x F34 and 744x206/71 were also good combiners. In general, the predominance of SCA sum of squares to GCA sum of squares indicated the relative importance of non-additive gene action for yield (Ayano et al., 2014; Bayeta, 1997) indicated the importance of additive and non-additive gene actions; non-additive being dominant.

\section{Existence of Heterosis in Coffee Arabica}

One of the ways to increase coffee production in Ethiopia is by the development of high yielding hybrids. To this effect, hybrid coffee variety development program in Ethiopia started since 1978 with hybrid vigour study. Since then, studies conducted on several sets of crosses consistently show the presence of considerable amount of heterosis in crosses among indigenous cultivars and possibility to improve coffee yield in Ethiopia through hybridization, which are originally collected from similar or different regions (Bayetta 2001 and Wasu 2004). From 1997 - 2002, three coffee hybrids; namely, Ababuna, $\mathrm{MCH}_{2}$ and Gawe were released. These hybrids give 24-26 Q/ha clean coffee in medium altitude coffee growing areas of South West Ethiopia; where as the best check and parent Dessu gave 18.2 Q/ha(Bayeta et al., 1998). However, Brazilian reported that absence heterosis in arabica coffee due to limited genetic diversity in Brazil. For example heterosis in percentage over the mid-parent (OMP) and better parent (OBP) for some seedling characteristics in coffee Arabica is indicated in the following table(1).

\section{Achievements Made}

The Jimma Research Center has released 26 coffee varieties (23 pure lines and 3 hybrids), which are high yielding, resistant to diseases, and possess unique inherent quality attributes of each locality. Recently, 12 pure line specialty coffee varieties (Wellega $=4$, Sidamo/Yirgacheffe $=3$, and Harar $=4$ ) have been identified and proposed respectively from Gimbi, Yirgacheffe/Sidamo and Harar coffee populations, which make a total of 37 improved coffee varieties in the country as summarized in table(2) (Kufa, 2010). Additionally about three hybrid coffee variety is approved by variety release 


\section{Desalegn Alemayehu}

committee and recommended for low and midland agro ecologies of south west Ethiopia. In general the achievements made were the result of genetic diversity within different agro ecologies of the country.

Table 1.

\begin{tabular}{|c|c|c|c|c|c|c|c|c|c|c|c|c|c|c|}
\hline \multirow[t]{2}{*}{ Hybrid } & \multicolumn{2}{|c|}{ Girth } & \multicolumn{2}{|c|}{ Height } & \multicolumn{2}{|c|}{$\begin{array}{c}\text { Internode } \\
\text { length }\end{array}$} & \multirow{2}{*}{\multicolumn{2}{|c|}{ 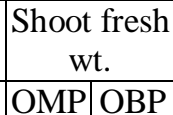 }} & \multicolumn{2}{|c|}{$\begin{array}{c}\text { Shoot dry } \\
\text { wt. }\end{array}$} & \multicolumn{2}{|c|}{ Shoot volume } & \multicolumn{2}{|c|}{ Leaf area } \\
\hline & OMP & OBP & OMP & OBP & OMP & OBP & & & OMP & OBP & OMP & OBP & OMP & C \\
\hline $74110 x$ & -1 & -2 & 3 & 2 & 6 & 6 & 9 & 1 & 7 & 0 & 9 & -1 & 15 & 12 \\
\hline & 7 & 5 & & & 12 & 6 & $24 * *$ & 12 & $33 * *$ & $22 *$ & $24 * *$ & 11 & $26 * *$ & 16 \\
\hline 7411 & $14 *$ & 6 & & $14 * *$ & $33^{* * *}$ & $25 * *$ & $65^{* *}$ & $64 * *$ & $58 * *$ & $57 * *$ & $69 * *$ & $69 * *$ & $44 * *$ & \\
\hline & $13 *$ & $11 *$ & & & $9 * *$ & $22 * *$ & $59 * *$ & $53 * *$ & $58 * *$ & $53 * *$ & $49 * *$ & $3 * *$ & $52 * *$ & 1 \\
\hline & 1 & 9* & $20^{3}$ & $20 * *$ & $25^{* *}$ & $25 * *$ & $52 * *$ & $44 * *$ & $44 * *$ & $38 * *$ & $49 * *$ & $43^{* *}$ & $54 * *$ & 0 \\
\hline 741 & 5 & 5 & -4 & & -6 & -11 & -3 & -5 & -1 & -6 & -7 & -8 & 6 & -1 \\
\hline 7415 & $15^{* *}$ & 6 & $11^{*}$ & 0 & $20 *$ & 1 & 11 & 1 & 15 & 7 & & -7 & 15 & 14 \\
\hline & 1 & & 5 & & 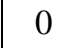 & -6 & & 4 & 9 & & & -1 & 10 & 4 \\
\hline & 2 & -2 & 10 & 9 & 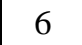 & 6 & $19 *$ & 16 & $19 *$ & 17 & 7 & 0 & $23 *$ & 20 \\
\hline 2007 & $12 * *$ & 7 & $24 *$ & 6 & $25^{* *}$ & 11 & $18^{* * *}$ & $33 * *$ & $44 * *$ & $31 * *$ & $52 * *$ & $37 * *$ & $36^{*}$ & $29 *$ \\
\hline & - & 5 & 9* & & $17 *$ & $17 *$ & 15 & 8 & 17 & 10 & 12 & 0 & 11 & 11 \\
\hline & 2 & -2 & 6 & & 6 & & & 2 & & & -1 & -8 & 13 & \\
\hline $221 \mathrm{~A}$ & -7 & $-11^{* *}$ & -8 & $-18^{* *}$ & $-19 *$ & $-28 * *$ & -7 & -11 & -8 & -12 & -14 & $-20^{*}$ & 13 & -17 \\
\hline $221 \mathrm{~A}$ & 2 & -3 & 6 & -2 & 0 & -6 & 12 & 5 & 9 & 3 & 6 & 2 & 13 & 11 \\
\hline 137 & $11 * *$ & $10 * *$ & $18^{* * *}$ & $14 * *$ & $24 * *$ & $17 * *$ & $39 * *$ & $36 * *$ & $39 * *$ & $37^{*}$ & $40 * *$ & $35^{* *}$ & $32 * *$ & $28 *$ \\
\hline Mean & 6 & 3 & 11 & 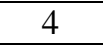 & 12 & 6 & 24 & 18 & 23 & 17 & 20 & 13 & 22 & 18 \\
\hline
\end{tabular}

*** Significant at 0.05 and 0.01 probability levels, respectively.

Source: Bayetta Bellachew, Mesfin Ameha, Dejene Mekonnen. 1993

Table 2. Coffee Varieties released by JRAC and area of adaptation.

\begin{tabular}{|c|c|c|c|c|c|c|c|c|}
\hline \multirow[b]{2}{*}{ No } & \multirow[b]{2}{*}{$\begin{array}{l}\text { Varieties } \\
\text { released }\end{array}$} & \multirow[b]{2}{*}{$\begin{array}{l}\text { Year of } \\
\text { released }\end{array}$} & \multicolumn{2}{|c|}{\begin{tabular}{|c|} 
Yield Q/ha \\
(Clean coffee)
\end{tabular}} & \multicolumn{3}{|c|}{ Area of adaptation } & \multirow[b]{2}{*}{ Example locations } \\
\hline & & & $\begin{array}{c}\text { On } \\
\text { esearch } \\
\text { field }\end{array}$ & $\begin{array}{c}\text { On } \\
\text { farmers } \\
\text { field }\end{array}$ & $\begin{array}{l}\text { Recommended } \\
\text { Altitude m.a.s. }\end{array}$ & $\begin{array}{c}\text { Rain fall } \\
(\mathrm{mm})\end{array}$ & $\begin{array}{c}\text { Temperature } \\
\left({ }^{0} \mathrm{C}\right)\end{array}$ & \\
\hline 1 & 741 & 1977/78 & 12.2 & $6-7$ & $1550-2100$ & $>1400$ & $11.0-28.0$ & Jimma, Gera, Agaro \\
\hline 2 & 744 & 1979/80 & 16.6 & $8-9$ & $1550-2100$ & $>1400$ & $11.0-28.0$ & Jimma, Gera, Metu, Wonago \\
\hline 3 & 7440 & 1979/80 & 16.2 & $8-9$ & $1000-2100$ & $>1400$ & $15.0-30.0$ & Gera, Jimma, Tepi \\
\hline 4 & 7454 & \begin{tabular}{|l|}
$1980 / 81$ \\
\end{tabular} & 18.3 & $8-9$ & $1000-2100$ & $>1400$ & $15.0-30.0$ & Gera, Tepi \\
\hline 5 & 7487 & $1980 / 81$ & 23.8 & $9-10$ & $1550-2100$ & $>1400$ & $11.0-28.0$ & Gera, Wonago \\
\hline 6 & 74110 & \begin{tabular}{|l|}
$1978 / 79$ \\
\end{tabular} & 19.1 & $9-10$ & $1550-2100$ & $>1400$ & $11.0-28.0$ & Gera, Jimma, Metu \\
\hline 7 & 74112 & 1978/79 & 18.1 & $9-10$ & $1550-2100$ & $>1400$ & $11.0-28.0$ & Gera, Jimma, Metu \\
\hline 8 & 74140 & \begin{tabular}{|l|}
$1978 / 79$ \\
\end{tabular} & 19.7 & $9-10$ & $1550-2100$ & $>1400$ & $11.0-28.0$ & Gera, Jimma, Metu \\
\hline 9 & 74148 & 1979/80 & 18.0 & $6-7$ & $1550-2100$ & $>1400$ & $11.0-28.0$ & Gera, Jimma, Metu \\
\hline 10 & 74158 & \begin{tabular}{|l|}
$1978 / 79$ \\
\end{tabular} & 19.1 & $9-10$ & $1550-2100$ & $>1400$ & $11.0-28.0$ & Gera, Jimma, Metu \\
\hline 11 & 74165 & \begin{tabular}{|l|}
$1978 / 79$ \\
\end{tabular} & 17.3 & $8-9$ & $1550-2100$ & $>1400$ & $11.0-28.0$ & Gera, Jimma, Metu \\
\hline 12 & 754 & \begin{tabular}{|l|}
$1980 / 81$ \\
\end{tabular} & 14.8 & $7-8$ & $1550-2100$ & $>1400$ & $11.0-28.0$ & Gera, Jimma, Metu \\
\hline 13 & 75227 & $1980 / 81$ & 17.9 & $8-9$ & $1550-2100$ & $>1400$ & $11.0-28.0$ & Gera, Jimma, Metu \\
\hline 14 & Dessu8 & 1998 & 18.2 & $13-15$ & $1000-1750$ & $>1400$ & $11.0-28.0$ & Jimma, Metu, goma, Tepi \\
\hline 15 & Catimor J-19 & 1998 & 16.6 & $9-12$ & $1000-1400$ & $>1400$ & $15.0-30.0$ & Bebeka, Tepi \\
\hline 16 & Catimor J-21 & 1998 & 19.4 & $13-15$ & $1000-1400$ & $>1400$ & $15.0-30.0$ & Bebeka, Tepi \\
\hline 17 & Ababuna 粠 & 1998 & 23.8 & $15-16$ & $1000-1750$ & 1500-1800 & $11.0-28.0$ & Metu, Jimma, Goma \\
\hline 18 & Melko CH2 粼 & 1998 & 24.0 & 13-15 & $1000-1750$ & $1500-1800$ & $11.0-28.0$ & Metu, Jimma, Gomma \\
\hline 19 & Me'oftu & 2002 & 21.2 & $15.7-21$ & $1550-1750$ & $1500-1800$ & $11.0-28.0$ & Jimma, Metu \\
\hline 20 & Gawe 粠 & 2002 & 26.0 & 24.0 & $1550-1750$ & $1500-1700$ & $11.0-28.0$ & Metu, Gomma, Jimma \\
\hline 21 & Gesiha & 2002 & $18-25.4$ & $10-12$ & $1000-1400$ & $1500-1700$ & $15.0-30.0$ & Bebeka, Tepi \\
\hline 22 & \begin{tabular}{|c|} 
Merda- \\
hereko(8136)
\end{tabular} & 2006 & 15.4 & 17.1 & $50-2100$ & 00 & -28.0 & Gera, Kota \& Sedi \\
\hline 22 & \begin{tabular}{|c|} 
Buno \\
Washi(7416)
\end{tabular} & 2006 & 23.5 & 15.6 & $1750-2100$ & 00 & $11.0-28.0$ & Gera, Kota \& Sedi \\
\hline 24 & Yachi(7576) & 2006 & 19.0 & 15.2 & 2100 & $>1400$ & $11.0-28.0$ & Gera, Kota \& Sedi \\
\hline 25 & Wushush(7514) & 2006 & 16.4 & 16.2 & $1750-2100$ & $>1400$ & $11.0-28.0$ & Gera, Kota \& Sedi \\
\hline 26 & Angefa(1377A) & 2006 & 20.4 & 16.2 & $1550-2100$ & $>1400$ & $11.0-28.0$ & ada\&Wenago(Sidama\&Ge \\
\hline
\end{tabular}




\section{SUMMARY AND CONCLUSION}

Coffee (Coffea arabica L.) belongs to the genus Coffea, in the family of Rubiaceae, and is mostly grown in the tropical and subtropical regions Ethiopia is the homeland and center of genetic diversity of Arabica coffee (Coffea arabica L., Rubiaceae). The entire genetic diversity of indigenous (wild) Arabica coffee is confined mainly in the afromontane rain forest located in the west and east of Great Rift Valley. More genetically diverse strains of C. Arabica exist in Ethiopia than anywhere else in the world, which has lead botanists and scientists to consent that Ethiopia is the center for origin, diversification and dissemination of the coffee plant. Several phenotypic and molecular studies revealed that the populations of $C$. arabica from the southwestern part of Ethiopia have high genetic variability, and the forests there are thus suitable for in situ conservation of the species.

The two broad categories of marker are used to detect genetic diversity in coffee Arabica; those are morphological marker and molecular markers (DNA based markers) such as RAPD, AFLP, SSR, ISSR and etc. Higher level of genetic variability with both markers was observed and reported by different scholars among spontaneous and sub spontaneous accessions of this species collected from different agro ecologies Ethiopia. For example Ethiopian cultivated coffee can be classified into 13 main types namely, Agaro, Arbagugu, Cioiccie, Coulo, Dilla, Ennarea, Harar, Irgalem, Keffa, Tafari Kela, Wolkite, Wollamo and Zeghie using only bean and fruit morphology. It can also be classified into wild and cultivated coffee. Molecular markers have been replacing or complementing traditional morphological and agronomic characterization, since they are virtually unlimited, cover the whole genome, are not influenced by the environment, and less time consuming. However, each molecular marker has its advantages and drawbacks.

The major indicators of Arabica coffee genetic diversity in Ethiopia is the achievements made by agricultural research like, ensuring the availability of heterosis in coffee, releasing resistant varieties to $\mathrm{CBD}$, phenotypic and genotypic variability existence study by many researchers and etc are the main contribution to indicate coffee genetic diversity within different agro ecologies of Ethiopia.

\section{REFERENCES}

[1] Adugna G, Hindorf H, Steiner U, Nirenberg H, Dehne I, et al. (2005) Genetic diversity in the coffee wilt pathogen (Gibberella xylarioides) populations: differentiation by host specialization and RAPD analysis. J Plant Dis Protect 112: 134-145.

[2] Allard, R.W. 1960. Principles of Plant Breeding. John Wiley and Sons. Inc. New York.

[3] Ameha, M., 1986. The significance of Ethiopian coffee genetic resources to coffee improvement. In the proceedings of an international symposium on the conservation and utilization of Ethiopian germplasm, pp. 247-253. Addis Ababa, Ethiopia, 13-16 October, 1986

[4] Ayano, A., Alamirew, S. and Tesfaye, A., Combining Ability for Yield and Morphological Characters in Southwestern Ethiopian Origin Coffee (Coffea Arabica L.) Hybrids.

[5] Bayetta Belachew, Behailu Atero and Gibramu Temesgen 1998. Description and Production recommendations for new cultivars of arabica coffee. IAR, research report No 34, A.A Ethiopia.

[6] Bayeta Belachew 2001. Arabica coffee breeding for yield and resistance to coffee berry disease (collectotrichum cahawe Sp. Nov.) A thesis submitted to the University of London in partial fulfillment of the requirements of the degree of Doctor philosophy, Wye College, university of London, U.K.

[7] Bart, M., Seneshaw, T., Tadesse, K. and Yaw, N., 2014. Structure and performance of Ethiopia's coffee export sector. Edited book Published by Ethiopian Development Research Institute and International Food Policy Research Institute in Ethiopia strategy support programme, 33.

[8] Beining, A. 2008. Ecophysiological diversity of wild Coffea arabica populations in Ethiopia: Drought adaptation and mechanisms. Ecology and Development Series Bd. 60, University of Bonn, Germany.

[9] Bellachew, B. 1997. Arabica coffee breeding in Ethiopia: a review. In: Proceedings of the 17 ASIC Colloquium (Nairobi), pp.406-416. ASIC Paris France

[10] Berhanu Tsegaye, Ali Mohammed, Tesfaye Shimber, Yehenew Getachew and Essubalew Getachew 2015.Impact of sun drying methods and layer thickness on the quality of highland Arabica coffee varieties at Limmu; South western Ethiopia.Basic Research Journal,pp. 12-20. 
[11] Bertrand, B., Alpizar, E., Lara, L., Santacreo, R., Hidalgo, M., Quijano, J.M., Montagnon, C., Georget, F. and Etienne, H., 2011. Performance of Coffea arabica F1 hybrids in agroforestry and full-sun cropping systems in comparison with American pure line cultivars. Euphytica, 181(2), pp.147-158.

[12] Berthaud J, Charrier A (1988) Genetic resources of Coffea. In: Clarke R J, Macrae R (eds), Coffee: Agronomy, vol. IV, pp.1-42. Elsevier Applied Science, London.

[13] Chauhan, R., Hooda, M.S. and Tanga, A.A., 2015. Coffee: The Backbone of Ethiopian Economy.

[14] CSA, 2010.Agricultural Sample Survey 2010/2011.Area and production of crops. Central Statistical Agency of Ethiopia, Addis Ababa

[15] Dabholkar, A.R. 1999.Elements of Biometrical Genetics. Concept Publishing Company, New Delhi.

[16] Davis, A.P., Gole, T.W., Baena, S. and Moat, J., 2012. The impact of climate change on indigenous arabica coffee (Coffea arabica): predicting future trends and identifying priorities. PLoS One, 7(11), p.e47981.

[17] Dessalegn, Y., Herselman, L. and Labuschagne, M., 2009. Comparison of SSR and AFLP analysis for genetic diversity assessment of Ethiopian arabica coffee genotypes. South African Journal of Plant and Soil, 26(2), pp.119-125.

[18] Dewey, D.R. and K.H. Lu, 1959. Acorrelation and path coefficient analysis of components of crested wheat grass seed production. Agronomy Journal ,51:515-518.

[19] Etienne, H., Anthony, F., Dussert, S., Fernandez, D., Lashermes, P. and Bertrand, B., 2002. Biotechnological applications for the improvement of coffee (Coffea arabica L.). In Vitro Cellular \& Developmental Biology-Plant, 38(2), pp.129-138.

[20] Geromel, C., Ferreira, L. P., Guerreiro, S. M. C., Cavalari, A. A., Pot, D.,Pereira, L. F. P., \& Marraccini, P. (2006). Biochemical and genomic analysis of sucrose metabolism during coffee (Coffea arabica) fruit development. Journal of Experimental Botany, 57(12), 3243-3258

[21] Gessese MK, Bellachew B, Jarso M (2015) Multivariate Analysis of Phenotypic Diversity in the South Ethiopian Coffee (Coffea arabica L.) for Quantitative Traits. Adv Crop Sci Tech S1: 003. doi:10.4172/2329-8863.S1-003

[22] Gole, T. W.M.and Teketay, D. (2001). The forest coffee ecosystems: on going crices, problems and apportunities for gene conservation and utilization. In: Imperative Problems Associated with Forestry in Ethiopia, Biological Society of Ethiopia Pp 131-142.

[23] ICO (International Coffee Organization) 2012. http//www.ico/org/trade_statistic.asp

[24] Karp, A., Kresovich, S., Bhat, K.V., Ayad, W.G. \& Hodgkin, T. 1997. Molecular tools in plant genetic conservation: a guide to the techniques. International Plant Genetic Resources Institute Technical Bulletin No. 2, pp. 5-47.

[25] Kebede, M. and Bellachew, B., 2004. Genetic divergence of Hararge coffee (Coffea arabica L) germplasm accessions at pre-bearing stage. In 20th International Conference on Coffee Science, 11th-15th October.

[26] Kebede, M., \& Bellachew, B. (2008). Phenotypic Diversity in the Hararge Coffee (Coffea arabica L) Germplasm for Quantitative Traits. East African Journal of Science, 2(1), 13-18.

[27] Kufa, T. 2006. Ecophysiological diversity of wild Arabica populations in Ethiopia: Growth, water relations and hydraulic characteristics along a climatic gradient. Gottingen, Cuvillier Verlag.

[28] Kufa, T., 2010, February. Environmental sustainability and coffee diversity in Africa. In ICO World Coffee Conference (pp. 26-28).

[29] Labouisse J-P, Bellachew B, Kotecha S, Bertrand B (2008) Current status of coffee (Coffea arabica L.) genetic resources in Ethiopia: implications for conservation. Genet Resour Crop Ev 55: 1079-1093

[30] Lashermes, P., Trouslot, P., Anthony, F., Comes, M.C. \& Charrier, A. 1996. Genetic diversity for RAPD markers between cultivated and wild accessions of Coffea arabica. Euphytica 87, 5964. 
[31] Lashermes, P., Combes, M. C., Ansaldi, C., Gichuru, E., \& Noir, S. (2011).Analysis of alien introgression in coffee tree (Coffea arabica L.) Mol Breeding, 27, 223-232. doi:10.1007/s11032010- 9424-2

[32] Mayo, O. 1980. The Theory of Plant Breeding. Oxford University Press, New York. 293 pp

[33] Mekuria, T., D. Neuhoff, U. Köpke, 2004.The Status of Coffee Production and Potential for Organic Conversion in Ethiopia.Conference on International Agricultural Research for Development.University of Bonn, Institute of Organic Agriculture. Bonn.

[34] Mesfin Ameha and Bayetta Belachew (1984), Resistance of the F1 to coffee berry disease in six parent diallel crosses in coffee. In: Proceedings of the first regional workshop on coffee berry disease. 19-23 July 1982, Addis Ababa, Ethiopia. pp 167-177

[35] Mesfin Ameha \& Bayetta Belachew 1987. Genotype-Environmental interactions in coffee (coffea arabica L.). 12 $2^{\text {th }}$. International scientific colloQuium on coffee (ASIC). Paris pp. 476482.

[36] Meyer FG, Fernie LM, Narasimhaswamy RL, Monaco LC, Greathead DJ (1968) FAO coffee mission to Ethiopia 1964-1965. FAO, Rome

[37] Montagnon, C. and Bouharmont, P. (1996). Multivariate analysis of phenotypic diversity of Coffea arabica. Genetic. Resour. Crop. Evol.43: 221 - 227.

[38] Motta, L.B., Soares, T.C.B., Ferrão, M.A.G., Caixeta, E.T., Lorenzoni, R.M. and Souza Neto, J.D.D., 2014. Molecular characterization of arabica and Conilon coffee plants genotypes by SSR and ISSR markers. Brazilian archives of biology and technology, 57(5), pp.728-735.

[39] Olika Kitila, Sentayehu Alamerew, Taye Kufa and Weyessa Garedew. 2011. Variability of quantitative Traits in Limmu Coffee (Coffea arabica L.) in Ethiopia. International Journal of Agricultural Research, 6: 482-493.

[40] Orozco-Castillo, C., Chalmers, K.J., Waugh, R. and Powell, W., 1994. Detection of genetic diversity and selective gene introgression in coffee using RAPD markers. TAG Theoretical and Applied Genetics, 87(8), pp.934-940.

[41] Pearl, H.M., Nagai, C., Moore, P.H., Steiger, D.L., Osgood, R.V. and Ming, R., 2004. Construction of a genetic map for arabica coffee. Theoretical and Applied Genetics, 108(5), pp.829-835.

[42] Powell, W., Orozco-Castillo, C., Chalmers, K.J., Provan, J. and Waugh, R., 1995. Polymerase chain reaction-based assays for the characterisation of plant genetic resources. Electrophoresis, 16(1), pp.1726-1730.

[43] Powell, W., Morgante, M., Andre, C., Hanafey, M., Vogel, J., Tingey, S. \& Rafalski, A. 1996. The comparison of RFLP, RAPD, AFLP and SSR (microsatellite) markers for germplasm analysis. Mol. Breed. 2, 225-238. Sabesan,T., Suresh,R. and Saravanan, K. 2009.Genetic variability and correlation for yield and grain quality characters of rice grown in costal saline low land of Tamiluadu. Electronic Journal of Plant Breeding. 1:56-59.

[44] Selvakumar, M. and Sreenivasan, M.S., 1989. Studies on morphology and quality of Ethiopian arabica coffee. Journal of Plantation Crops, 16, pp.321-324.

[45] Sharma, J.R.1998. Statistical and biometrical techniques in plant breeding. New Age International (P) limited, publishers. New Delhi. 432p.

[46] Sylvain, P.C. 1955. Some observation on Coffea arabica L. in Ethiopia. Turrialba 5, 37-53.

[47] Sylvain, P.G., 1958. Ethiopian Coffee: Its significance to world coffee problems. Botany 12: 111139.

[48] Taye, K., Tesfaye, S. and Alemseged, Y. 2004. Adaptation of Arabica coffee landraces along topographic gradients in southern Ethiopia. In: Proceedings of the 20th International Conference on Coffee Science (ASIC), 11-15 October 2004, Bangalore, India, 1046-1052.

[49] TayeK.and Jurgen, 2008.Ecophysiolog of wild coffeaine population in mountane rain forestwelgekno of Ethiopia .Proceedings of coffee knowledge and diversity .work shop of EIAR .Addis

[50] Van der Vossen, H.A.H. 1985. Coffee selection and breeding. In M.N. Clifford \& K.C. Willson (eds) Coffee: Botany, Biochemistry and production of beans and beverage, Croom Helm, London, New York \& Sydney, pp.48-96. 
[51] Van der Vossen, H.A.H. 2001. Agronomy I: Coffee breeding Practices. In: R:J. Clake \& O:G. Vitzthum (eds) Coffee Recent Development, Blackwell Science Ltd, London, pp.184-201.

[52] Vavilov, N.I., 1951. The origin, variation, immunity and breeding of cultivated plants (Vol. 72, No. 6, p. 482). LWW

[53] Wang, Z.Y. \& Tanksley, S.D. 1989. Restriction length polymorphism in Oryza sativa L. Genome $32,1113-1118$.

[54] Walyaro .D.J.A 1983. Consideration in breeding of improved yield and Quality in arabica coffee (coffee arabica L.) Wagengen, the Neitherlands.

[55] Wassu mohammed 2004. Heterosis and combining ability analysis of yield and yield related traits in coffee (coffea arabica.L).Msc. thesis presented to the school of graduate studies, Alemaya university, Ethiopia.

[56] Welsh. J.R. 1990. Fundamentals of Plant Genetics and Breeding. Robert E. Krieger Publishing Company. Malbara, Florida. 290 pp.32Breeding. Robert E. Krieger Publishing Company. Malbara, Florida. 290 pp.

[57] Yacob, E., Tesfaye, S., Taye, K., Alemseged, Y., Takele, N., Anteneh N. and Bekele, B. 1996. Advances in coffee agronomy research in Ethiopia. Pp 40-45. In: Tenywa J.S., Adipala Ekwamu, M.W. Ogengalatogo (Eds.). Proceedings of Inter-Africa Coffee Organization (IACO) Workshop, 4-6 Sept., 1995, Kampala, Uganda.

[58] Yeshitila, K. (2004). Prospects of forest genetic resources conservation, In: Proceeding of the public meeting on integrated forest policy Dervelopment in Ethiopia, Forumfor Environment (FfE), Institute of biodiversity, Addis Ababa.

Citation: D. Alemayehu, "Review on Genetic Diversity of Coffee (Coffea Arabica. L) in Ethiopia", International Journal of forestry and Horticulture (IJFH), vol. 3, no. 2, p. 10, 2017, http:// dx.doi.org/10. 20431/2454-9487.0302003.

Copyright: (C) 2017 Authors. This is an open-access article distributed under the terms of the Creative Commons Attribution License, which permits unrestricted use, distribution, and reproduction in any medium, provided the original author and source are credited. 